\title{
Deteksi Dini Gangguan Jiwa Dan Masalah Psikososial Dengan Menggunakan Self Re- porting Qustioner (SRQ-29)
}

\author{
Larasuci Arini ${ }^{1}$, Setiadi Syarli ${ }^{2}$ \\ 1,2 Dosen Keperawatan Institut Kesehatan Mitra Bunda, Indonesia
}

\section{INFORMASI ABSTRACT}

Korespondensi:

larasuci.arini78@gmail. com

Keywords:

Mental Disorder,PTSD, Deperession, Anxiety,Drugs
Objective: This research is intended to conduct screening / early detection of psychosocial problems and mental disorders to prevent and overcome them in the Riau Islands, especially the city of Batam.

Method: This study uses a descriptive design with a cross-sectional study approach. Random sampling with several respondents as many as 196 respondents. The instrument used was Self Reporting-29 (SRQ-29). The study was carried out during September 2019

Results: The results found: anxiety and depression (28\%), indications of the use of psychoactive substances (4\%), psychotic disorders (21\%), PTSD (32\%) and no indicated disorders (15\%).

Based on this study, it was concluded that the most common Conclusion:Problems found were PTSD, anxiety and depression and psychotic disorders. With this study, active participation from all parties, government and stakeholders are expected. Early prevention and screening will be more effective and efficient in overcoming psychosocial problems and mental disorders in the community. 


\section{PENDAHULUAN}

Jumlah penderita gangguan jiwa dari tahun ke tahun mengalami peningkatan. WHO (2009) memperkirakan 450 juta orang di seluruh dunia mengalami gangguan mental, sekitar $10 \%$ adalah orang dewasa dan $25 \%$ penduduk diperkirakan akan mengalami gangguan jiwa pada usia tertentu selama hidupnya. Menurut National Alliance of Mental Illness (NAMI) berdasarkan hasil sensus penduduk Amerika Serikat tahun 2013, di perkirakan 61.5 juta penduduk yang berusia lebih dari 18 tahun mengalami gangguan jiwa, 13,6 juta diantaranya mengalami gangguan jiwa berat seperti skizofrenia, gangguan bipolar dll (NAMI, 2013)

Indonesia merupakan Negara berkembang dengan jumlah penderita gangguan jiwa yang cukup besar. Data hasil riset kesehatan dasar tahun 2013 (Depkes, 2013) yang dilakukan oleh Badan Penelitian Pengembangan Kesehatan Departemen Kesehatan, menunjukkan prevalensi gangguan jiwa di Indonesia sebesar 1.7 permil, artinya dari 1000 penduduk Indonesia, maka satu sampai dua orang diantaranya menderita gangguan jiwa berat.

Riset Kesehatan Dasar (Riskedas) 2013 mencatat, prevalensi gangguan jiwa berat di Kepri mencapai 1,3 per mil. Angka ini dua poin lebih tinggi dibandingkan DKI Jakarta (1,1 mil). Sementara di Ibu Kota Provinsi Kepri, terdapat 200 lebih warganya yang mengalami gangguan jiwa. Berdasarkan data Dinas Sosial Kota Batam pada 2010 jumlah orang dengan gangguan jiwa di Batam yang dikirim ke RSJ Pekanbaru hanya 24 orang. Sementara pada 2012 jumlah orang dengan gangguan jiwa meningkat hingga 10 penderita setiap bulannya (Riskedas,2013). Tren ODGJ yang terus meningkat berdasarkan data yang diterima dari Dinkes kota Batam tahun 2019, total Orang Dengan Gangguan Jiwa (ODGJ) berat di Batam ada sebanyak 521 orang.

Besarnya angka prevalensi penduduk dengan gangguan jiwa menimbulkan dampak cukup besar bagi suatu negara. Menurut informasi Kementerian Kesehatan beban ekonomi akibat gangguan jiwa lebih besar (Rp20 T) dibandingkan dengan kerugian ekonomi dalam menangani kasus TBC (Rp6,2 T) (ROKOM, 2011)

\section{METODE}

Studi ini merupakan penelitian deskriptif dengan pendekatan crosssectional study. Dalam studi ini dilakukan pengambilan sampel dilakukan dengan teknik random sampling dari beberapa wilayah di Kota batam yang melibatkan 196 responden. Responden dalam penelitian ini ditentukan berdasarkan kriteria inklusi usia $\geq 17$ Tahun s/d usia 35 Tahun (referensi). Alat ukur berupa Instrumen Self-Reporting-29 (SRQ29) dipilih untuk mendeteksi masalah psikososial dan gangguan jiwa yang diadopsi dari sehat-jiwa Kemenkes. Studi ini dilakukan pada bulan Juli s/d Agustus 2019.

\section{HASIL}

Hasil penelitian ini diuraikan sebagai berikut :

Tabel.1 Hasil Penelitian Deteksi Dini Masalah Psikososial dan Gangguan Jiwa dengan Self Reported Questionaire (SRQ-29) (N=196)

\begin{tabular}{llcc}
\hline No. & \multicolumn{1}{c}{ Klasifikasi } & $\begin{array}{c}\text { Frekuen- } \\
\text { si }\end{array}$ & $\begin{array}{c}\text { Presen- } \\
\text { tase \% }\end{array}$ \\
\hline & Cemas dan Depresi & 55 & 28 \\
\hline $\begin{array}{l}\text { Penggunaan Zat Psikoaktif/ } \\
\text { Narkoba }\end{array}$ & 8 & 4 \\
\hline 3. & Gangguan Psikotik & 42 & 21 \\
\hline $4 . \quad \begin{array}{l}\text { Post Traumatik Distres } \\
\text { Syndrom (PTSD) }\end{array}$ & 63 & 32 \\
\hline 5. Tidak terindikasi gangguan & 29 & 15 \\
\hline \multicolumn{2}{l}{ Total } & 196 & 100 \\
\hline sumber : data primer, 2019) & &
\end{tabular}

Hasil penelitian pada table.1 menunjukkan bahwa, masalah psikososial yang ditemukan melalui studi ini secara berurutan dari yang paling tinggi ke yang paling rendah adalah Post Traumatic Distress Syndrom (PTSD), yakni sebanyak 63 repsonden (32\%), cemas dan depresi, yaitu sebanyak 55 responden (28\%), Gangguan Psikotik sebanyak 42 orang responden (21\%) dan penggunaan zat psikoaktif.narkoba sebanyak 8 orang responden (4\%). Sedangkan sebanyak 29 responden (15\%) tidak terindikasi mengalami masalah psikosial maupun gangguan jiwa.

\section{Post Traumatic Distress Syndrom (PTSD)}

Hasil penelitian ini menunujukkan bahwa PTSD merupakan masalah psikososial yang paling banyak ditemukan dengan frekuensi sebesar 32\% atau sebanyak 63 responden $(\mathrm{n}=196)$. Menurut American Psychiatric Association (2013) PTSD adalah kondisi mental di mana Anda mengalami serangan panik yang dipicu oleh trauma pengalaman masa lalu. Definisi lain menyebutkan PTSD adalah gangguan mental yang dapat berkembang setelah terpapar dengan peristiwa yang sangat mengancam atau mengerikan (Bonanno GA, 2004; Jonathan, 2015). 
Menurut studi yang dilakukan Kessler et al (2014) Prevalensi kejadian PTSD telah ditemukan berkisar antara 1 hingga 6 persen dalam sampel populasi orang dewasa umum di seluruh dunia (sampel yang diambil dari 24 negara). Sedangkan hasil Studi WHO (2017) menunjukkan bahwa prevalensi PTSD seumur hidup di negara-negara berpenghasilan menengah ke atas dan menengah ke bawah masing-masing 2,3 dan 2,1 persen. Studi Koenen (2017) di Amerika Serikat Pada 5692 responden, ditemukan sebanyak 82,7 persen terpapar pada peristiwa parah dan berpotensi traumatis, dan 8,3 persen dari trauma yang terpapar didiagnosis dengan PTSD. Sementara itu, Studi yang dilakukan Creamer et al (2001) pada 10.641 orang di Australia diperoleh prevalensi PTSD sebesar 1,0 persen. Sedangkan di Indonesia belum ditemukan penelitian yang secara spesifik menyebutkan prevalensi PTSD secara nasional.

PTSD memilki manifestasi klinis yang bervariasi bergantung pada berbagai faktor yang mempengaruhi diantaranya adalah jenis trauma, usia, gender, social ekonomi yang rendah, pendidikan, Perpisahan (Konflik Rumah Tangga) trauma sebelumnya; kesulitan masa kecil umum; riwayat kejiwaan pribadi dan keluarga; melaporkan pelecehan anak; dukungan sosial yang buruk; dan keparahan awal reaksi terhadap trauma (Jitender, 2020). Menurit American Psychiatric Association (2013). Manifestasi klinis yang muncul pada seorang dewasa harus mengalami hal berikut ini sekurang-kurangnya dalam jangka waktu satu bulan: 1) satu gejala pengalaman yang berulang, 2) satu gejala menghindar 3) satu gejala peningkatan intensitas emosi dan gejala peningkatan reaksi, 4) dua gejala daya pikir dan gejala alam perasaan (mood symptoms). Namun, studi epidemiologi oleh Smid et al (2009) menemukan bahwa sekitar 25 persen mengalami onset tertunda setelah enam bulan atau lebih.

Studi PTSD sangat penting dilakukan sebagai upaya pencegahan/skrinning sebelum menimbulkan dampak yang luas pada individu yan terdampak. Permasalahan PTSD yamg tidak ditangani dengan baik menimbulkan berbagai dampak diantaranya menurut penelitian Karstoft $\mathrm{K}$ et al (2015) PTSD berdampak resiko pada kesehatan fisik yang buruk, termasuk somatoform, kardiorespirasi, muskuloskeletal, gastrointestinal, dan gangguan imunologis. Orang dengan PTSD beresiko lebih tinggi dalam permasalahan pekerjaan, dukungan social yang buruk, masalah hubungan intim, termasuk kesulitan perkawinan, dibandingkan dengan orang tanpa PTSD (Solomon, 1997). PTSD juga memicu resiko untuk bunuh diri (Wilcox et al, 2009 dan Bernal et al 2007).

\section{Cemas dan Depresi}

Hasil studi ini menunjukkan gangguan cemas dan depresi berada pada urutan ke 2 terbanyak yaitu sebesar 28\% (55 responden). Kecemasan dan Depresi adalah gangguan mental yang nyata dan umum terjadi sekarang ini (WHO, 2017). Menurut Mental Health Foundation (2013) kejadian Depresi dan kecemasan merupakan gangguan mental yang sering dijumpai dalam kehidupan.

Gangguan depresi adalah gangguan mental umum yang ditandai dengan gangguan perasaan atau mood, kehilangan minat atau kesenangan, perasaan bersalah atau harga diri yang rendah, susah tidur, penurunan nafsu makan, energi rendah, dan konsentrasi yang buruk (WHO, 2012). WHO juga menyebutkan pada kondisi yang parah Depresi dapat memicu seseorang untuk bunuh diri.

Berdasarkan Diagnostic and Statistical Manual of Mental Disorder, Fifth Edition (DSM-V), seseorang dikatakan depresi jika setidaknya selama dua minggu mengalami minimal lima dari sembilan kriteria berikut, yaitu (1) adanya perasaan depresi yang muncul di sebagian besar waktu, bahkan hampir setiap hari, (2) adanya penurunan minat dan kesenangan dihampir sebagian besar kegiatan dan hampir setiap hari, (3) adanya perubahan berat badan atau nafsu makan yang signifikan, (4) adanya perubahan tidur: menjadi insomnia atau hipersomnia, (5) adanya perubahan aktivitas, (6) merasa kelelahan dan kehilangan energi, (7) munculnya perasaan bersalah atau tidak berharga yang berlebihan dan sebenarnya tidak pantas muncul, (8) mengalami penurunan konsentrasi, dan (9) memiliki pikiran berulang tentang kematian (tidak hanya takut mati), adanya keinginan bunuh diri berulang tanpa rencana spesifik, usaha bunuh diri, atau rencana spesifik untuk melakukan bunuh diri (Dianovinina, 2018).

Menurut Cestari et al (2017), Kecemasan adalah serangkaian respons yang mencakup kombinasi kompleks dari perasaan takut, khawatir berlebihan, depresi, kegelisahan dan pemikiran yang tidak relevan dari seorang individu dan disertai dengan sensasi fisik seperti jantung berdebar, nyeri dada, dan / atau sesak napas. Dalam tingkat sedang, kecemasan merangsang respons antisipatif dan adaptif terhadap acara yang menantang dan menegangkan. Hal ini biasa terjadi dimana seseorang mengalami perubahan situasi dalam hidupnya dan dituntut untuk mampu. Beradaptasi (Marasmis, 2009). Menurut penelitian (Patimah dkk., 2015) cemas merupakan respon emosional yang tidak menyenangkan terhadap berbagai macam stressor baik yang jelas maupun tidak teridentifikasikan yang ditandai dengan adanya sebuah perasaan takut, khawatir, dan perasaan terancam

Tanda Gejala :

a.Mengalami kecemasan dan kekhawatiran yang berlebihan

b. Tidak stabil secara emosional

c. Merasa putus asa atau frustasi

d.Selalu merasa lelah dan tak bertenaga

e.Mengalami pusing dan rasa nyeri tanpa penyebab yang jelas

f. Menurunnya selera makan

Penyebab :

a. Mengalami peristiwa traumatis.

b.Memiliki penyakit kronis atau serius.

c. Mengonsumsi jenis obat tertentu.

d.Memiliki riwayat gangguan mental lainnya.

Faktor lain yang dapat menyebabkan kecemasan yai- 
tu faktor predisposisi yang terdiri dari psikoanalitis, interpersonal, perilaku, perspektif keluarga dan perspektif biologis. Faktor presipitasi yang terdiri dari Ancaman terhadap integritas fisik dan Ancaman terhadap sistem diri (Stuart \& Sundeen, 2007 dalam Fauziah et al, 2018).

\section{Gangguan Psikotik}

Psikosis adalah gangguan jiwa yang ditandai oleh gangguan menilai realitas. Psikosis terdiri dari beragam jenis antara lain skizofrenia, skizoafektif, gangguan waham menetap, bipolar dengan ciri psikotik, depresi dengan ciri psikotik. Psikotik akut dan sementara juga merupakan gangguan yang sama, tetapi merupakan gangguan yang akut dan mempunyai prognosis lebih baik (Sadock, 2015).

Menurut (Tomb, 2004) Psikosis berarti menunjukkan derajat keparahan bukan gangguan yang spesifik. Pasien psikotik mengalami gangguan penilaian realita yang berat dan disertai disabilitas kognitif dan emosi. Banyak faktor yang menyebabkan seseorang mengalami gejala psikotik, diantaranya adalah penyalahgunaan zat psikoaktif. Menurut penelitian Tyler et al (2016) menunjukkan bahwa orang dengan riwayat penyalahgunaan zat psikoaktif dua kali lipat lebih banyak mengalami gejala psikotik dibandingkan dengan populasi umum. Hal ini juga didukung oleh penelitian lainnya oleh Romer et al (2017) dan penelitian Kim et al (2017).

Orang dengan gejala gangguan psikotik diketahui melalui hasil pemeriksaan. Pada pemeriksaan psikiatri didapatkan kesan umum penampilan tampak wajar, roman muka sedih dan kontak verbal dan visual cukup, kesadarannya jernih, mood sedih, afek sedih, keserasian tampak serasi (appropiate), pada proses pikir bentuk pikir logis realis, arus pikir koheren, isi pikir preokupasi pada kondisi saat ini, pencerapan didapatkan halusinasi auditorik dan halusinasi visual, dorongan instingtual terdapat insomnia ada tipe early, hipobulia ada, raptus tidak ada dan psikomotor tenang saat pemeriksaan.(Yustiana et al,2019).

Prevalensi psikosis 1,8 per 1000 penduduk menurut Riskesdas 2018 sedikit lebih tinggi dibandingkan hasil Riskesdas 2013 yang menyebutkan pevalensi psikosis 1,7 per 1000 penduduk (dengan metode sama seperti yang disebut di atas 1,5 per 1000 penduduk). Namun data baiknya menyebutkan untuk masalah psikosis tidak termasuk dalam wilayah dengan prevalensi psikosis tertinggi (termasuk dalam kelompok provinsi terendah adalah wilayah Indonesia bagian timur. Berbeda dengan hasil penelitian yang dilakukan penulis, dimana Hasil studi ini menunjukkan gangguan psikosis berada pada urutan ke 3 terbanyak yaitu sebesar 21\% (42 responden). Provinsi yang tinggi prevalensinya antara lain Provinsi DI Yogyakarta, Bali, Nusa Tenggara Barat, Jawa Tengah dan Sulawesi Selatan.

\section{Penggunaan Zat Psikoaktif dan Narkoba}

Zat adiktif adalah suatu bahan atau zat yang apabila digunakan dapat menimbulkan kecanduan atau ketergantun- gan. Tanda dan gejala penggunaan zat psikoaktif / narkoba diantaranya adalah :1) Intoksikasi yang menyebabkan perubahan memori, perilaku,kognitif, alam perasaan dan kesadaran,2) Kondisi toleransi (overdosis), 3) Sindroma putus zat (withdrawal) (Yusuf, 2015).

Berdasarkan studi ini, indikasi penyalahgunaan zat psikoaktif dan narkoba hanya teridentifikasi sebanyak $4 \%$ (8 orang responden), meskipun demikian angka ini juga harus menjadi perhatian, mengingat angka kasus penyalahgunaan narkoba saat ini cukup tinggi di Indonesia. Data pengguna Narkoba yang teridentifikasi menurut Wiliam (2015) yaitu Jawa Barat (790.000 orang),Jawa Timur (560.000 orang), Jawa Tengah (440.000 or-ang), DKI Jakarta (360.000 orang), Sumatera Utara (295.000 orang), Banten (175.000 orang), Sulawesi Selatan (140.000 orang), Sumatera Selatan (100.000 orang), Riau (90.000 orang), Lampung (90.000 orang). Dari data tersebut setidaknya tercatat 3,8-4,1 juta penduduk Indonesia adalah pengguna narkoba atau setara dengan $2,18 \%$ penduduk usia 10-59 tahun. Sedangkan, data BNN (2014) menyebutkan DKI Jakarta memiliki angka prevalensi tertinggi (4,73\%) disusul oleh Kalimantan Timur (3,07\%) dan Kepulauan Riau (2,94\%). Prevalensi penyalahguna NAPZA di Indonesia setiap tahun selalu meningkat. Pada tahun 2011 prevalensinya sebesar $2,32 \%$, tahun 2013 sebesar 2,56\%, dan tahun 2015 sebesar 2,80\% (BNN RI, 2016). Sedangkan, Laporan perkembangan situasi NAPZA dunia tahun 2014 menyatakan angka estimasi pengguna tahun 2012 adalah antara 162 juta hingga 324 juta orang atau sekitar 3,5-7\%. Estimasi pengguna NAPZA tahun 2010 yang kisarannya 3,5-5,7\% (UNODC, 2014). Mengingat prevalensinya yang terus meingkat, tentu hal ini akan menimbulkan dampak yang sangat besar. Menurut BNN RI (2010), dampak dari penyalahgunaan NAPZA dikenal dengan istilah $4 \mathrm{~L}$ yaitu liver, lover, lifestyle, dan legal. Liver merupakan dampak langsung yang menyerang penyalahguna NAPZA dan dapat merusak organ vital seperti otak, hati, paru, dan ginjal. Lover berarti adanya hubungan yang rusak dengan orang yang dicintai misalnya keluarga. Penyalahguna biasanya selalu dalam pengaruh NAPZA sehingga selalu menomorsatukan zat tersebut sehingga membuat dirinya lupa akan kewajiban dan tidak lagi memperdulikan orang lain. Lifestyle yang rusak ditandai dengan kondisi dirinya yang merasa malas untuk melakukan sesuatu, sering bolos sehingga prestasi sekolah menurun yang menyebabkan putus sekolah, dan cita-cita berantakan.

Selain itu, bahaya penggunaan zat psikoaktif yang berkelanjutan juga berhubungan dengan berkembangnya gejala depresif, gejala positif dan negatif dan menurunkan fungsi pasien secara umum (Gregorio, 2016). Dampak lain pelanyalahgunaan narkoba pada pasien dengan riwayat penggunaan zat psikoaktif multipel serta pada hasil pemeriksaan status mental diantaranya adalah adanya halusinasi berupa auditorik dan visual serta waham kebesaran dan waham kejaran dan ada gangguan emosi berupa mood hipotimia serta afek yang terbatas. Pasien memiliki 
masalah pergaulan yang salah serta dukungan keluarga yang kurang terhadap keadaan pasien karena kurangnya pengetahuan mengenai kondisi pasien. Pasien didiagnosis gangguan psikotik onset lama akibat penggunaan zat psikoaktif multipel dna diberikan terapi berupa psikofarmaka, psikoterapi dan psikoedukasi (Yustiana et all,2019)

\section{KESIMPULAN}

Hasil studi ini menunjukkan pentingnya upaya pencegahan dan deteksi lebih awal pada gangguan jiwa dan masalah psikososial pada masyarakat guna menekan dampak yang lebih luas pada masalah lainnya yang mencakup masalah kesehatan, ekonomi sosial dan budaya masyarakat di Indonesia, khususnya Kepulauan Riau. Keterlibatan berbagai pihak terkait yang bersinergi dengan masyarakat akan lebih efektif dalam hal pencegahan. Hasil penelitian ini masih memiliki keterbatasan dalam hal generalisasi sampel. Dibutuhkan sampel yang lebih besar sebagai lanjutan studi ini..

\section{SARAN}

Dengan adanya studi ini diharapkan patisipasi aktif dari semua pihak, pemeritah dan stakeholder. Pencegahan dan skrining secara dini akan lebih efektif dan efisien dalam penanggulangan masalah psikososial dan gangguan jiwa ditengah masyarakat.

\section{DAFTAR PUSTAKA}

Badan Narkotika Nasional Republik Indonesia. 2010. Pelajar dan Bahaya Narkotika. Jakarta: Deputi Bidang Pencegahan Direktorat Diserminasi Informasi.

Bernal M, Haro JM, Bernert S, et al. Risk factors for suicidality in Europe: results from the ESEMED study. J Affect Disord 2007; 101:27.

BNN. (2014). Laporan Akhir Survei Nasional PerkembanganPenyalahgunaan Narkoba Tahun Anggaran 2014. Jakarta: BNN.

Cestari V, Barbosa .I, Floencio.R, Pessoa .V \& Moreira.T. Stress in nursing students: study on socio-demographic and academic vulnerabilities. Acta Faul Enferm , 2017; 30 (2): 190-6

Creamer M, Burgess P, McFarlane AC. Post-traumatic stress disorder: findings from the Australian National Survey of Mental Health and Well-being. Psychol Med 2001; 31:1237.

Dianovinina, Ktut. (2018). Depresi pada Remaja: Gejala dan Permasalahannya. Jurnal Psikogenesis, Volume 6, No.1, Juni 2018. Fakultas Psikologi, Universitas Surabaya .
Gregorio D De, Comai S, Posa L, Gobbi G. Acid Diethylamide ( LSD ) as a Model of Psychosis : Mechanism of Action and Pharmacology D -Lysergic. International Journal of Molecular Science. 2016;7:1- 20.

Hendriasti. Sinta. V.L (2018). Drug-free ASEAN 2025: Tantangan Indonesia dalam Penanggulangan Penyalahgunaan Narkoba. Jurnal Hubungan Internasional. vol. 7, No. 1 / April - September 2018. https://doi.org/10.18196/hi.71122

Jitender, Sareen. (2020). Literature Review : Posttraumatic stress disorder in adults: Epidemiology, pathophysiology, clinical manifestations, course, assessment, and diagnosis. Diakses dari https:// www.uptodate.com/contents/posttraumatic-stress-disorder-in-adults-epidemiology-pathophysiology-clinical-manifestations-course-assessment-and-diagnosis

Kessler RC, Rose S, Koenen KC, et al. How well can post-traumatic stress disorder be predicted from pre-trauma risk factors? An exploratory study in the WHO World Mental Health Surveys. World Psychiatry 2014; 13:265.

Kim W, Jang S, Chun SY, Lee T, Han K, Park E. Mortality in Schizophrenia and Other Psychoses : Data from the South Korea National Health Insurance Cohort, 2002-2013. J Korean Medical Science. 2017; 32:835-842.

Koenen KC, Ratanatharathorn A, Ng L, et al. Posttraumatic stress disorder in the World Mental Health Surveys. Psychol Med 2017; 47:2260.

Marasmis, 2009. Catatan Ilmu Kedokteran Jiwa. Surabaya: Airlangga University Press, pp:38,107, 252-254.

Mental Health Foundation. Mental Health Foundation; 2013. Starting Today: Future of Mental Health Services [Online] Available at: https:// www.mentalhealth.org.uk/publications/startingtoday-future-of-mental-health-services

Patimah, I., Suryani. \& Nuraeni, A. 2015. Pengaruh Relaksasi Dzikir terhadap Tingkat Kecemasan Pasien Gagal Ginjal Kronis yang Menjalani Hemodialisa. Jurnal Keperawatan Padjadjaran Vol. 3 No. 1.

Rikesdas. (2018).Laporan Riset Kesehatan Dasar. Indonesia

Rikesdas. (2013).Laporan Riset Kesehatan Dasar. Indonesia

ROKOM.(2011).http://sehatnegeriku.kemkes. go.id/baca/rilismedia/20110928/401673/har- 
gailah-penderita-gangguan-jiwa/

Sadock BJ, Sadock VA, Ruiz P. Schizophrenia spectrum and other psychotic disorders 2015. In: Kaplan and Sadock's synopsis of psychiatry [Internet]. New York: Wolters Kluwer. 11 th

Smid GE, Mooren TT, van der Mast RC, et al. Delayed posttraumatic stress disorder: systematic review, meta-analysis, and meta-regression analysis of prospective studies. J Clin Psychiatry 2009; 70:1572.

Solomon SD, Davidson JR. Trauma: prevalence, impairment, service use, and cost. J Clin Psychiatry 1997; 58 Suppl 9:5.

Tomb, David.A.(2004) Buku Saku Psikiatri. Penerbit Buku Kedokteran EGC

Tyler O, Matthew S, Melanie R, John H. A Case of Aggressive Psychosis in The Setting of Regular Dextromethorphan Abuse. J Psychosomatics. 2016.

Romer K, Thylstrup B, Mulbjerg M, Uffe M, Simonsen E, Hesse M. Drug-related Predictors of Readmission for Schizophrenia Among Patients Admitted to Treatment for Drug Use Disorders. J Elsevier. 2017.

United Nations Offi ce on Drug and Crime (UNODC). 2012. World Drug Report. United Nations Publication.

[WHO] World Health Organization. Depression [internet]. 2012 [cited 6 Maret 2020]; Avaiable from http://www.who.int/ topics/ depression/en/

Wilcox HC, Storr CL, Breslau N. Posttraumatic stress disorder and suicide attempts in a community sample of urban american young adults. Arch Gen Psychiatry 2009; 66:305.

Yustiana, Anastasia Venny., Aryani. Luh Nyoman Alit. (2019). Gangguan psikotik akibat penggunaan ganja (cannabis): studi kasus. MEDICINA 2019, Volume 50, Number 2: 400-403 P-ISSN.2540-8313, E-ISSN.2540-8321 